\title{
Alokasi Daya Kirim pada Visible Light Communication menggunakan Algoritma Waterfilling
}

\author{
DIAH AYU LESTARI, ARFIANTO FAHMI, BRIAN PAMUKTI
}

\author{
Teknik Telekomunikasi Universitas Telkom, Indonesia \\ Email: diahayulestari2210@gmail.com
}

Received 7 Agustus 2020 | Revised 3 September 2020 | Accepted 18 September 2020

\begin{abstract}
ABSTRAK
Peningkatan terhadap kebutuhan akses data membuat Visible Light Communication (VLC) menjadi alternatif media transmisi nirkabel yang efisien. Namun berdasarkan performansinya, VLC memiliki permasalahan data rate yang tidak merata diterima oleh User Equipment (UE). Dalam mengatasi permasalahan tersebut, penelitian ini menerapkan alokasi daya kirim dengan algoritma waterfilling yang mampu memberikan keadilan data rate setiap UE berdasarkan nilai kanal. Penelitian ini menggunakan kanal Line Of Sight (LOS) dengan 3 skenario berbeda. Kami menggunakan parameter validasi untuk mengukur setiap kinerja dengan nilai Signal Noise Ratio (SNR), data rate, fairness index dan efisiensi energi. Dari hasil simulasi menggunakan algoritma waterfilling, kami memperoleh nilai fairness index untuk data rate sebesar 100\% namun tidak memiliki efisiensi daya. Dengan memodifikasi algorima waterfilling, terjadi penurunan fairness index, SNR serta data rate, tapi memberikan efisiensi energi LED hingga 9\%. Dengan demikan, daya yang dipancarkan oleh LED memiliki lifetime yang lebih panjang dengan modified waterfilling.
\end{abstract}

Kata kunci: VLC, Power Allocation, Waterfilling, Fairness.

\begin{abstract}
The increase in the need for data access makes Visible Light Communication (VLC) an alternative wireless transmission medium that is efficient. However, based on its performance, VLC has a data rate problem that is not evenly accepted by User Equipment (UE). In overcoming this problem, this study applies power allocation with waterfilling algorithm that is able to provide fair data rate for each UE based on channel value. This study uses the Line Of Sight (LOS) channel with 3 different scenarios. We use validation parameters to measure each performance using the Signal Noise Ratio (SNR) value, data rate, fairness index and energy efficiency. From the results of simulation using the waterfilling algorithm, we obtain a fairness index value for the data rate of $100 \%$ but does not have a power efficiency. By modifying the waterfilling algorithm, there is a decrease in the fairness index, SNR and data rate, but provide $L E D$ energy efficiency of up to $9 \%$. Thus, the power emitted by the LED has a longer lifetime with modified waterfilling algorithm.
\end{abstract}

Keywords: VLC, Power Allocation, Waterfilling, Fairness. 


\section{PENDAHULUAN}

Saat ini kebutuhan terhadap kecepatan akses dan efisiensi transmisi data digital semakin meningkat. Oleh sebab itu, dibutuhkan alternatif teknologi komunikasi nirkabel yang menawarkan hal tersebut salah satunya yaitu Visible Light Communication (VLC). Teknologi VLC mampu memberikan efisiensi transmisi data di dalam ruangan serta kecepatan akses data yang tinggi dengan menggunakan media transmisi cahaya tampak. VLC juga memiliki kelebihan untuk dapat diterapkan di beberapa tempat seperti Stasiun Pengisian Bahan Bakar Umum (SPBU), kabin pesawat, rumah sakit, bangunan industri dan juga ruangan yang terdapat reaktor nuklir.

Selain itu spektrum cahaya tampak juga belum dibatasi oleh regulasi frekuensi sehingga memiliki peluang yang besar untuk dikembangkan, namun VLC memiliki jarak jangkauan yang terbatas dan coverage yang kecil (Farabi, dkk, 2019). Berdasarkan karakteristiknya, VLC saat ini memiliki isu dalam proses distribusi daya kirim yang tidak merata di setiap pengguna sehingga pengguna yang berada di jarak lebih jauh dari sumber mendapatkan nilai SNR yang lebih rendah daripada pengguna pada jarak terdekat dengan sumber LED yang akan berpengaruh terhadap data rate. Berdasarkan penelitian (Praneeth Varma, dkk, 2018) bahwa Signal to Noise Ratio (SNR) mengalami degradasi daya hingga ke bagian sudut ruangan pada sistem VLC. Maka dibuat skema algoritma heuristik yaitu menggunakan prinsip stokastik geometri dalam alokasi daya sehingga mendapatkan penerangan merata dan meningkatkan SNR.

Tahun 2016 terdapat penelitian (Wan, dkk, 2017) membahas tentang dua skema alokasi daya dalam memaksimalkan throughput dan fairness pada sistem VLC. Pada penelitian (Xing, dkk, 2020) di tahun 2019 bahwa algoritma waterfilling dinilai cukup berguna dalam optimasi sistem komunikasi wireless. Algoritma tersebut mampu menjadi solusi mendasar dalam menyelesaikan masalah performansi jaringan dan juga penting dalam desain komunikasi nirkabel, desain pemrosesan sinyal, dan optimasi jaringan termasuk optimasi transceiver, alokasi sumber daya, dan lain sebagainya.

Selanjutnya berdasarkan asumsi dan teori dari referensi yang sudah dibahas, maka penelitian ini dimaksudkan untuk menyimulasikan dan menerapkan algoritma waterfilling dalam model sistem VLC sebagai teknik alokasi daya kirim. Algoritma tersebut akan diamati dan dianalisis dampak yang terjadi terhadap performansi jaringan VLC termasuk nilai SNR dan fairness data rate setiap user. Penelitian ini diharapkan mampu meningkatan nilai fairness data rate pada sistem VLC.

Visible Light Communication (VLC) adalah teknologi sistem komunikasi dengan memanfaatkan spektrum cahaya tampak sebagai medianya transmisi dengan panjang gelombang antara 375 nm sampai dengan $780 \mathrm{~nm}$ (400-800 Thz) (Trihantoro, dkk, 2014).

Light Emiting Diode (LED) merupakan dioda semikonduktor yang memancarkan sinyal optik/cahaya. LED memiliki lebar spektral $40 \mathrm{~nm}$ pada panjang gelombang $850 \mathrm{~nm}$ dan $80 \mathrm{~nm}$ pada panjang gelombang 1300 nm (Damayanti, dkk, 2014).

Photodioda Positive-Intrinsic-Negative (PIN) merupakan komponen penerima cahaya yang terdiri dari daerah-p dan daerah-n yang dipisahkan oleh daerah intrinsik yang didop dengan sedikit-n. Prinsip kerja PIN dengan mengubah foton input menjadi arus output berdasarkan photovoltaic effect dan memerlukan reverse bias sebesar 5-20 volt untuk menggambarkan arus carrier yang keluar dari daerah intrinsik (Muthaqien, dkk, 2018). 
Resource allocation merupakan proses dalam melakukan pengalokasian sumber daya ke beberapa perangkat penerima di dalam satu cakupan maupun sistem yang sama. Hal ini penting dalam sebuah sistem multiple access karena sumber daya seperti halnya data rate, frekuensi, timeslot dan lain sebagainya terbatas.

Algoritma waterfilling adalah algoritma atau metode yang digunakan untuk mengalokasikan daya ke UE.

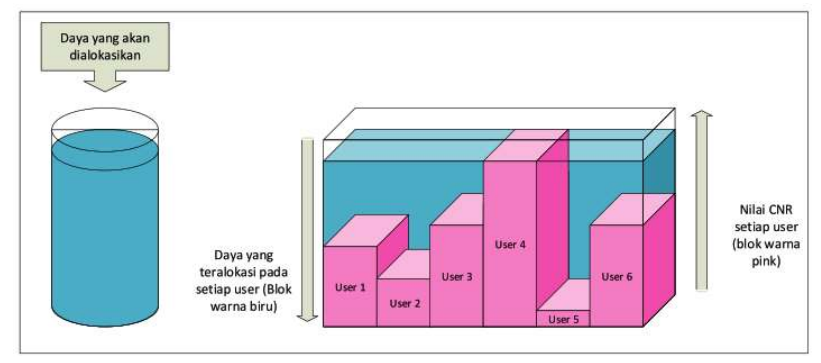

Gambar 1. Ilustrasi Prinsip Waterfilling (Sgora, dkk, 2015).

Algoritma waterfilling merupakan metode dengan menggunakan prinsip pengisian air pada suatu wadah dimana terdapat susunan balok dengan memiliki ketinggian air yang berbedabeda (Muthaqien, dkk, 2018). Alokasi sumber menggunakan algoritma waterfilling dirumuskan dengan Persamaan (1).

$$
P(n, v)=\frac{\frac{1}{H(n, v)}}{\sum_{n=1}^{N} \sum_{v=1}^{V} \frac{1}{H(n, v)}} P t
$$

dengan $\mathrm{P}(\mathrm{n}, \mathrm{v})$ merupakan daya yang dialokasikan pada kanal ke-v dan UE ke- $\mathrm{N}$ di timeslot$\mathrm{s}$, kemudian Pt merupakan total daya dari transmitter, dan $\mathrm{H}(\mathrm{n} ; \mathrm{v})$ adalah nilai CQI.

Signal to Noise Ratio (SNR) adalah perbandingan sinyal keluaran terhadap noise yang diterima pada saat proses transmisi sinyal. SNR juga dapat digunakan sebagai tolak ukur parameter performansi. Nilai SNR dapat dinyatakan dengan Persamaan (2) (Ghassemlooy, dkk, 2017).

$$
S N R=\frac{\left(P_{r x} \cdot R \cdot M\right)^{2}}{2 \cdot q \cdot\left(I_{p}\right) \cdot B \cdot M^{2} \cdot F(M)+2 \cdot q \cdot\left(I_{d}\right) \cdot B \cdot M^{2} \cdot F(M)+\frac{4 \cdot K_{B} \cdot T \cdot B}{R_{L}}}
$$

dengan SNR adalah Signal to Noise Ratio (dB), Pr adalah daya jatuh pada APD (Watt), R adalah responsivitas detektor $(\mathrm{A} / \mathrm{W}), \mathrm{M}$ adalah penguatan detektor, $\mathrm{q}$ adalah muatan elektron sebesar $1,69 \times 10^{-19} \mathrm{C}, I_{p}$ merupakan arus primer, $I_{D}$ merupakan arus dark, $\mathrm{F}(\mathrm{M})$ adalah Noise Figure, $\mathrm{B}$ adalah receiver electrical bandwidth $(\mathrm{Hz}), \mathrm{Kb}$ adalah Konstanta Boltzman sebesar $1,38 \times 10^{23}$ $\mathrm{J} / \mathrm{K}, \mathrm{T}$ adalah suhu photodetector $\left({ }^{\circ} \mathrm{K}\right), \mathrm{R}_{\mathrm{L}}$ adalah hambatan dalam (Ohm).

Fairness Index (FI) merupakan nilai kesamaan yang didapatkan dari perlakuan sumber terhadap masing-masing UE dalam memperoleh resource. Dalam mencari nilai fairness index digunakan metode Jain's Fairness Index yang diformulasikan dengan persamaan fairness index (Sari, dkk, 2015) :

$$
f(x)=\frac{\left(\sum x\right)^{2}}{n\left(\sum x\right)^{2}}
$$


dengan $f$ adalah nilai fairness index, $x$ merupakan nilai data rate dari setiap UE, dan $n$ adalah jumlah UE dalam sistem.

Energy Efficiency merupakan usaha untuk mengurangi jumlah energi yang dibutuhkan untuk menentukan titik optimal suatu sistem dapat bekerja. Faktor efficiency banyak digunakan dalam industri dalam mengukur tingkat efisiensi suatu produk/layanan. Berikut persamaan dalam menghitung ratio energy efficiency (Patterson, 1996) :

$$
\text { Energy Efficiency }=\frac{\text { Usable Energy }}{\text { Total Energy }} \times 100 \% \text {, }
$$

dengan Energy Efficiency adalah ratio efisiensi energi. Usable Energy adalah daya yang diterima oleh masing-masing UE. Total Energy adalah daya total yang berasal dari sumber.

Kapasitas kanal atau data rate merupakan ukuran kecepatan bit data dalam proses transmisi dari pengirim ke penerima, dalam satuan bit per detik. Namun dalam perkembangannya dapat diturunkan dalam satuan lain, diantaranya yaitu dalam karakter per second, word per second, word per minute dan lain sebagainya. Dalam mencari nilai data rate dapat menggunakan pendekatan persamaan Shannon-Hartley sebagai berikut (Wang, dkk, 2017) :

$$
C=B \log _{2}(1+S N R)
$$

dengan C adalah maksimum kapasitas dari kanal (bit/detik), B adalah bandwidth dari kanal (Hertz), dan SNR adalah Signal to Noise Ratio.

\section{METODOLOGI PENELITIAN}

\subsection{Desain Model Sistem}
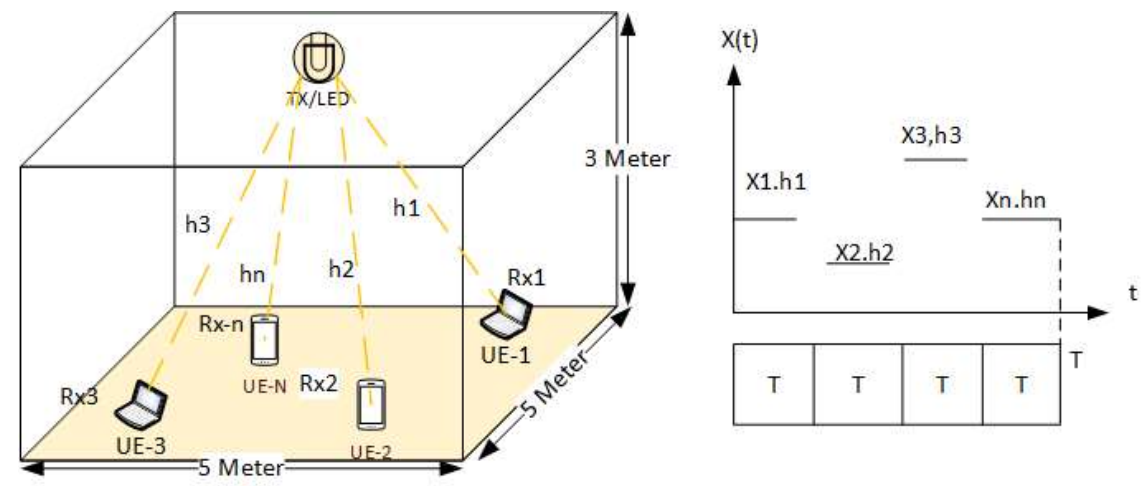

Gambar 2. Pemodelan Sistem VLC (Abdelhady, dkk, 2019).

Pada desain model sistem penelitian ini di ilustrasikan seperti Gambar 2. Sistem VLC ini ditempatkan pada sebuah ruangan berbentuk persegi dimana sebuah lampu LED terletak di tengah ruangan sebagai pengirim sinyal informasi melalui cahaya tampak. User Equipment (UE) yang memiliki photodetector sebagai penerima tersebar secara acak di ruangan. Kanal pada sistem VLC menggunakan Line of Sight (LOS) tanpa interferensi cahaya lainnya. Pada sumbu $X$ merupakan waktu atau timeslot sedangkan sumbu $Y$ merupakan pengirim ke-n dengan daya total dan nilai kanalnya masing-masing. Setiap receiver mendapatkan jumlah 
timeslot yang sama dengan nilai kanal yang berbeda tergantung dari jarak receiver terhadap transmitter (Abdelhady, dkk, 2019).

\subsection{Blok Diagram Sistem}

Perancangan model sistem dari penelitian ini adalah sebagai berikut. Gambar 3 di bawah merupakan blok sistem VLC yang secara garis besar terbagi atas tiga blok yaitu blok transmitter, blok kanal dan blok receiver.

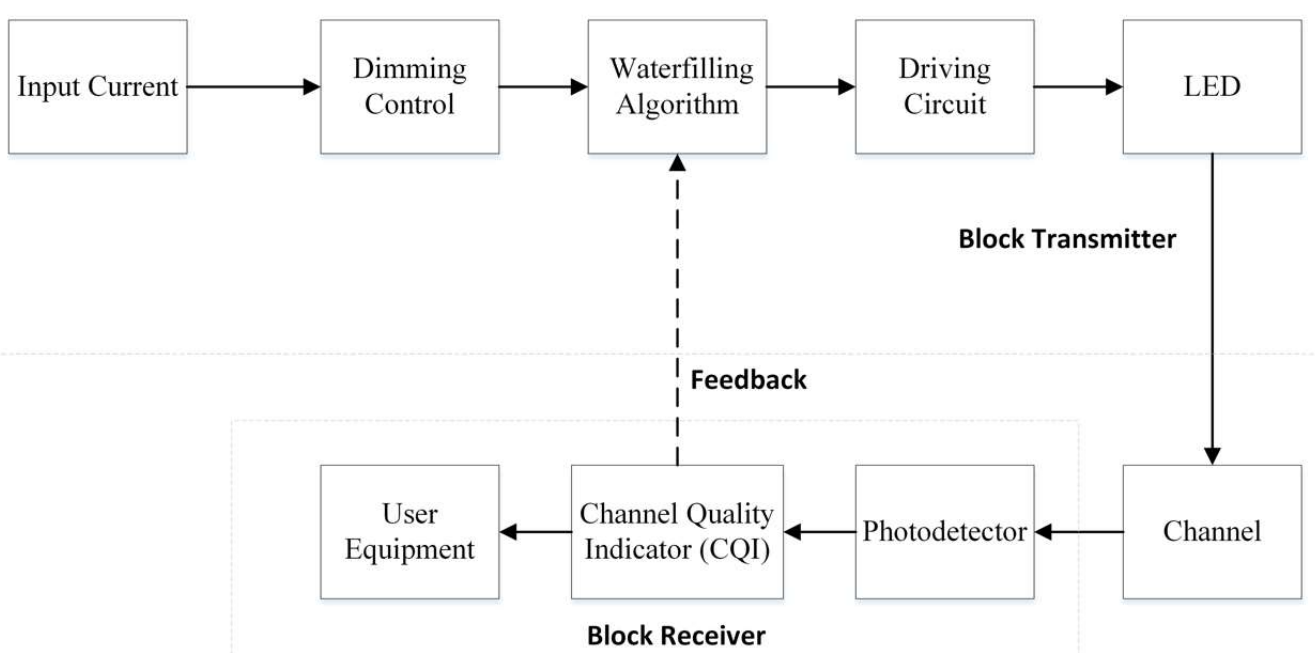

Gambar 3. Blok Diagram Sistem Visible Light Communication (Wijayanto, dkk, 2019).

Blok transmitter berfungsi memodulasi dan sebagai sumber transmisi sinyal informasi yang dikirimkan ke blok receivermelalui kanal transmisi VLC. Injeksi sumber listrik oleh input current berupa tegangan 220 VAC menuju ke rangkaian dimming control. Rangkaian dimming control berfungsi sebagai pengatur voltase pada sinyal listrik seperti saklar dengan potensio di dalamnya. Jika tegangan diturunkan oleh potensio maka intensitas cahaya lampu LED akan lebih redup dan sebaliknya. Pada penelitian ini, algoritma waterfilling digunakan sebagai metode dalam transmit power allocation Visible Light Communication (VLC). Diharapkan dengan adanya algoritma tersebut akan tercapai nilai fairness sistem yang tinggi pada simulasi model sistem. Data digital yang sudah terbentuk ditumpangkan ke dalam sinyal pembawa (carrier). Sinyal carrier berupa cahaya yang akan digabungkan pada rangkaian driving circuit di dalam lampu LED. Pada driving circuit sinyal listrik dan sinyal digital sudah digabungkan. Selain itu, driving circuit juga berfungsi untuk mengaktifkan LED beserta komponen di dalamnya. Rancangan model sistem pada penelitian ini menggunakan lampu LED sebanyak 1 buah dengan daya 9000 mW. Lampu LED memiliki Field of View (FoV) sebesar 70 derajat dan FoV hanya ada di penerima/receiver.

Blok kanal pada sistem VLC merupakan media transmisi dalam bentuk cahaya bebas tanpa ada perantara seperti halnya serat optik. Oleh sebab itu, karakteristik kanal VLC yang digunakan pada simulasi penelitian ini adalah kanal Line of Sight (LOS), dimana propagasi cahaya sebagai media transmisi merambat di dalam ruangan yang tidak terganggu oleh interferensi maupun noise seperti asap, debu, ataupun benda yang menghalangi serta membiaskan cahaya dari transmitter ke receiver. Pada simulasi penelitian ini menggunakan ruangan dengan dimensi panjang $x$ lebar $x$ tinggi sebesar $5 \mathrm{~m}$ x $5 \mathrm{~m} \times 3 \mathrm{~m}$. 
Blok receiver hanya berisi rangkaian photodetector dan User Equipment. Berikut prinsip kerjanya. Photodetector menangkap intensitas cahaya dan mengubah besaran cahaya yang ditangkap oleh sensor menjadi arus listrik kembali. Arus listrik yang diterima dikalkulasi ke dalam bentuk daya terima (power receive). Daya terima tersebut yang nantinya menjadi feedback dalam bentuk matriks CQI/nilai kanal untuk menentukan resource allocation pada algoritma waterfilling. Dalam penelitian ini photodetector yang digunakan adalah Positive Intristic Negative (PIN) dengan nilai responsivitas 0.55 dan index bias pada konsentrator sebesar 1,45. Pada User Equipment(UE) sinyal digital sudah didemodulasikan ke dalam bentuk sinyal informasi. UE merupakan perangkat yang berhubungan dengan user seperti laptop, handphone dan lain-lain.

\subsection{Spesifikasi Sistem Visible Light Communication}

Kebutuhan sistem pada penelitian ini yaitu ukuran ruangan 5 meter $\times 5$ meter $\times 3$ meter. Selain itu, bandwidth sistem Visible Light Communication (VLC) yang digunakan adalah $20 \mathrm{Mhz}$. Sistem menggunakan lampu LED sebanyak 1 (satu) buah di tengan-tengah ruangan dengan daya 9 Watt. Pada saat simulasi karakteristik dari fotodioda jenis ini didesain untuk memiliki luas permukaan sebesar $1 \mathrm{~cm}^{2}$ serta responsivitas dari PIN sebesar 0,55 dan FoV hanya dimiliki oleh penerima/receiver. UE pada simulasi penelitian ini berjumlah 5 UE sampai 25 UE dengan kelipatan 5 tiap simulasinya posisi UE tersebar secara acak di dalam ruangan (Pamukti, dkk, 2019). Pada penelitian ini kami mempertimbangkan beberapa parameter, seperti yang ditujukan pada Tabel 1.

Tabel 1. Parameter Simulasi.

\begin{tabular}{|l|l|l|}
\hline \multicolumn{2}{|l|}{ Parameter } & Nilai \\
\hline Ruangan & Ukuran & $5 \mathrm{~m} \times 5 \mathrm{~m} \times 3 \mathrm{~m}$ \\
\hline & Jenis & Lampu LED \\
\hline & Jumlah & 1 Buah \\
\hline & Data LED & $5 \mathrm{Watt}$ \\
\hline & Koodinat LED & $(2.5 ; 2.5 ; 3)$ ditengah ruangan \\
\hline & Bandwidth VLC & $20 \mathrm{Mhz}$ \\
\hline Fotodioda & Area detector & $1 \mathrm{~cm}$ \\
\hline & Responsivitas & $0,55 \mathrm{~A} / \mathrm{W}$ \\
\hline & FOV & 70 derajat \\
\hline UE & Jumlah & $5 \mathrm{~s} / \mathrm{d} 25$ (dengan kelipatan 5$)$ \\
\hline & Posisi UE & Acak/random \\
\hline Modulasi & Jenis & OOK-NRZ \\
\hline
\end{tabular}

\subsection{Simulasi}

Terdapat 3 skenario simulasi pada sistem VLC. Skenario pertama adalah simulasi tanpa menggunakan algoritma waterfilling yang ditampilkan pada Gambar 4(a). Skenario kedua merupakan simulasi penelitian menggunakan skema waterfilling seperti pada Gambar 4(b). Proses simulasi dengan algortima waterfilling memiliki tahapan yang sama dengan tanpa waterfilling sampai pada proses perhitungan kanal setiap UE sebagai CQI/nilai kanal. Pada skenario ketiga yang ditampilkan pada Gambar 4(c), diterapkan algoritma modifikasi waterfilling yaitu dengan memberi batasan pada pengalokasian daya minimum menjadi 100 Mw dan 75 mW dan maksimum 1800 mW guna melihat nilai efisiensi energi. 


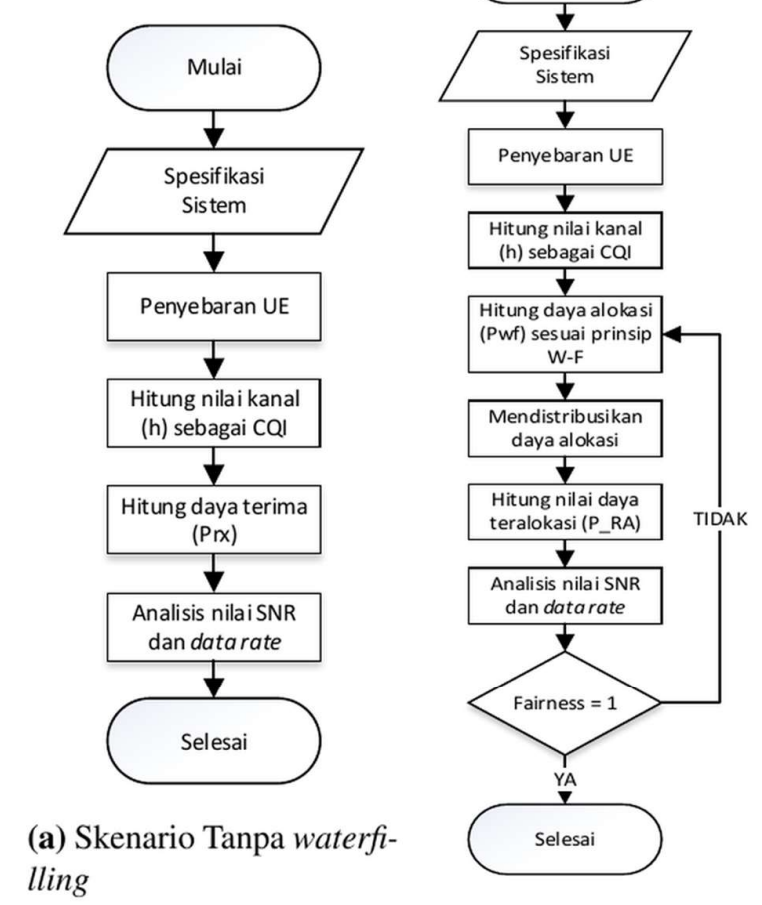

(b) Skenario Algoritma waterfilling

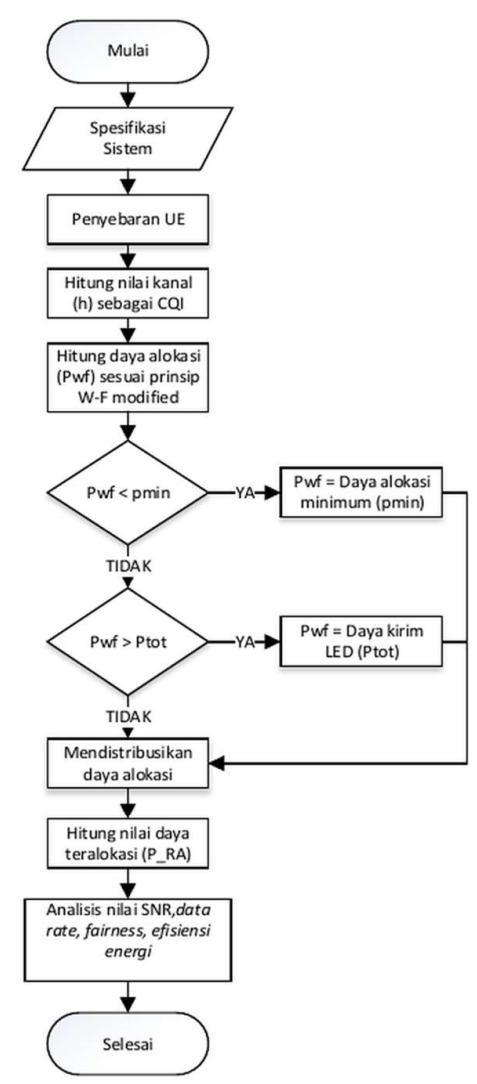

(c) Skenario Algoritma modified waterfilling

\section{Gambar 4. Diagram Alir Skenario Simulasi.}

\subsection{Penyebaran User Equipment}

Penyebaran UE dilakukan dalam kondisi tidak bergerak ( $f$ ixed), dimana UE tersebar secara acak di dalam ruangan. $\mathrm{h}$ merupakan tinggi ruangan yaitu 3 meter, sedangkan $\mathrm{d} 1<\mathrm{d} 2<\mathrm{d} 3$ merupakan jarak UE terhadap LED. Nilai jarak UE akan menentukan besaran nilai kanal yang selanjutnya dikirim sebagai feedback dalam bentuk Channel Quality Indicator (CQI). CQI mengacu kepada kondisi kanal masing-masing UE pada sistem VLC. Simulasi pada ruangan 5x5×3 meter didapatkan jarak maksimal sebesar 4,164 meter dan jarak minimal sebesar 2,2 meter.

\section{HASIL DAN PEMBAHASAN}

\subsection{Hasil Simulasi Pengalokasian Daya}

Pada proses pengalokasian UE telah mengirimkan informasi balik (feedback) sesuai kondisi kanal berupa nilai daya yang terbaca pada matrik CQI. Matrik CQI yang sudah terbentuk digunakan sebagai informasi awal untuk pengalokasian daya pada simulasi algoritma waterfilling. Berikut ini hasil pengalokasian daya dengan daya kirim total $9 \mathrm{~W}$ sebelum dilakukan pengalokasian daya. 
Tabel 2. Tabel Nilai Kanal (CQI) dan Daya Terima Sebelum dan Sesudah Waterfilling 5 UE.

\begin{tabular}{|c|c|c|c|c|}
\hline UE & Kanal (CQI) & $\begin{array}{c}\text { Daya Terima } \\
\text { Sebelum Wf }\end{array}$ & $\begin{array}{c}\text { Daya Yang } \\
\text { Dialokasikan }\end{array}$ & $\begin{array}{c}\text { Daya Terima } \\
\text { Sesudah Wf }\end{array}$ \\
\hline 1 & $2.32 \times 10^{-6}$ & $4.18 \times 10^{-6} \mathrm{~W}$ & $2.722 \mathrm{~W}$ & $6.32 \times 10^{-6} \mathrm{~W}$ \\
\hline 2 & $1.06 \times 10^{-5}$ & $1.91 \times 10^{-5} \mathrm{~W}$ & $0.594 \mathrm{~W}$ & $6.32 \times 10^{-6} \mathrm{~W}$ \\
\hline 3 & $4.58 \times 10^{-6}$ & $8.24 \times 10^{-6} \mathrm{~W}$ & $1.380 \mathrm{~W}$ & $6.32 \times 10^{-6} \mathrm{~W}$ \\
\hline 4 & $5.64 \times 10^{-6}$ & $1.01 \times 10^{-5} \mathrm{~W}$ & $1.121 \mathrm{~W}$ & $6.32 \times 10^{-6} \mathrm{~W}$ \\
\hline 5 & $3.17 \times 10^{-6}$ & $5.71 \times 10^{-6} \mathrm{~W}$ & $1.991 \mathrm{~W}$ & $6.32 \times 10^{-6} \mathrm{~W}$ \\
\hline
\end{tabular}

Tabel 2 merupakan hasil simulasi sebelum dan sesudah pengalokasian dengan 5 UE. Pada perhitungan nilai kanal sebagai CQI didapatkan nilai acak dengan matriks baris adalah User Equipment (UE) dan kolom merupakan Time Slot (TS). Semakin dekat UE terhadap sumber maka mendapatkan daya terima yang besar dan mendapatkan nilai kanal yang lebih baik, semakin jauh dari sumber akan mendapatkan kanal yang lebih kecil. Pada nilai kanal yang paling baik ditandai dengan kolom berwarna biru yaitu sebesar 1,06 x 10 dan daya terima sebelum waterfilling sebesar $1,91 \times 10^{-5} \mathrm{~W}$, sehingga mendapatkan daya alokasi paling kecil yaitu sebesar 0,594 W. Pada nilai kanal yang paling buruk ditandai dengan kolom berwarna merah yaitu sebesar 2,32 x $10^{-6}$ dan daya terima sebelum waterfilling sebesar 4,18 $\times 10^{-6} \mathrm{~W}$, sehingga mendapatkan daya alokasi paling besar yaitu sebesar 2,722 W. Pada hasil simulasi daya yang diterima tiap UE setelah algortima waterfilling adalah sama yaitu sebesar $6,32 \times 10^{-6} \mathrm{~W}$. Berikut ini adalah hasil dari simulasi dengan jumlah $10 \mathrm{UE}$.

\subsection{Hasil Parameter SNR}

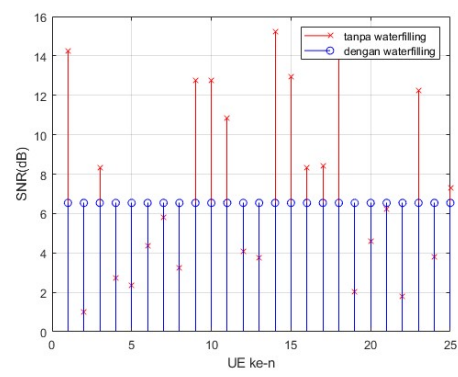

(a)

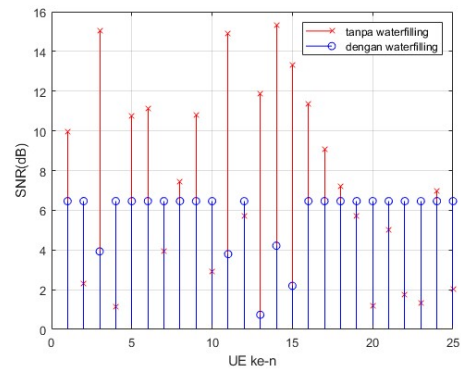

(b)

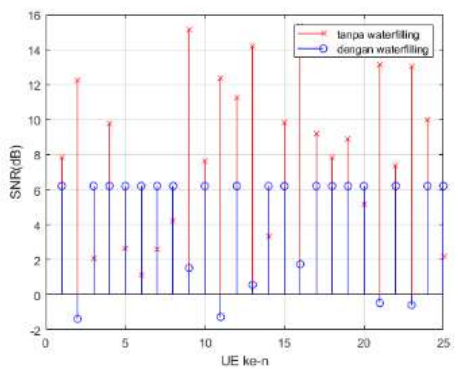

(c)

\section{Gambar 5. (a) Algortima Waterfilling Basic (b) Algoritma wf Modified min. 100mW (c)} Algoritma wf Modified min 75mW.

Pada Gambar 5(a) terlihat bahwa simbol silang merah mewakili hasil perhitungan SNR tanpa algoritma waterfilling bernilai acak terhadap 25 UE. Rentang nilai SNR dimulai dari $1 \mathrm{~dB}$ sampai dengan 15,21 dB, setelah menggunakan algortima waterfilling didapatkan hasil SNR yang rata sebesar 6,5 dB. Selain itu algoritma waterfilling juga berhasil meningkatkan nilai SNR pada UE yang terjauh dari sumber. Pada Gambar 5(b) algoritma waterfilling dilakukan modifikasi terhadap daya alokasi minimum dan maksimum maka akan berdampak pada penurunan ratarata nilai $34 \mathrm{~dB}$. SNR menjadi $6,45 \mathrm{~dB}$, sedangkan pada Gambar 5 (c) penurunan nilai SNR menjadi 6,2 dB. Pada algoritma yang dimodifikasi terdapat SNR yang tidak sama dengan SNR rata-rata, hal tersebut disebabkan karena UE yang telah mendapatkan SNR lebih besar 
diberikan pengurangan daya alokasi sehingga SNR UE tersebut turun. Hal ini akan dijelaskan pada bagian efisensi energi.

\subsection{Hasil Parameter Data rate}

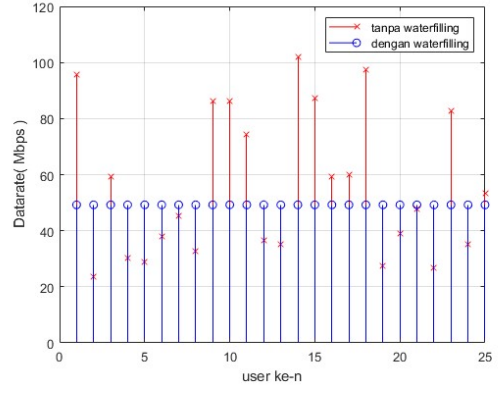

(a)

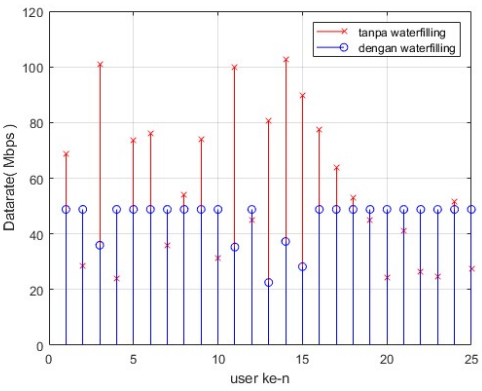

(b)

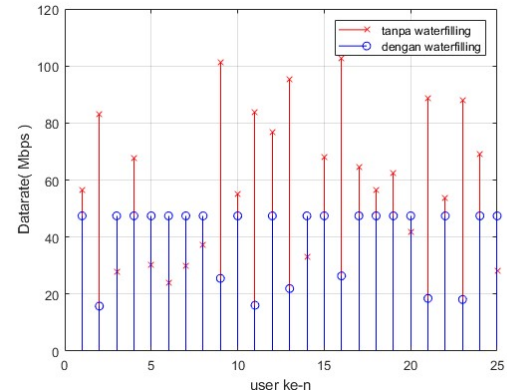

(c)

\section{Gambar 6. (a) Algortima Waterfilling Basic(b) Algoritma wf Modified min. 100mW (c) Algoritma wf Modified min 75mW.}

Pada Gambar 6(a) sistem yang menggunakan algoritma waterfilling basic mendapatkan ratarata data rate sebesar 49,22 Mbps. Algoritma waterfilling basic mampu memberikan data rate yang merata karena tidak ada daya alokasi minimum. Namun ketika sistem VLC menggunakan algoritma waterfilling modified atau diberikan alokasi daya minimum sebesar $100 \mathrm{~mW}$ dan 75 $\mathrm{mW}$ maka menghasilkan grafik yang tidak merata. Dapat dilihat jika dibandingkan antara Gambar 6(b) sistem menggunakan algoritma waterfilling alokasi daya minimum sebesar 100 $\mathrm{mW}$ dengan Gambar 6(c) sistem menggunakan algoritma waterfilling dengan alokasi daya minimum sebesar $75 \mathrm{~mW}$ menghasilkan nilai data rate yang tidak beraturan. Semakin besar ditingkatkan nilai alokasi daya minimum maka nilai data rate akan lebih bervariasi dan lebih turun. Hal tersebut dikarenakan UE yang mendapatkan kanal kecil hanya dibatasi oleh alokasi daya maksimal $1800 \mathrm{~mW}$ sesuai dengan daya total maksimum. Selain itu, jika daya alokasi dibatasi dan jumlah UE yang terlalu banyak akan mengurangi kapasitas data yang diterima pada sistem Indoor VLC. Hal tersebut disebabkan oleh daya pancar pengirim yang terlalu rendah walaupun memiliki data rate yang tinggi. Alokasi daya yang diberikan ke masingmasing UE berdasarkan nilai kanal (CQI) yang menjadi feedback antara UE dan sumber.

\subsection{Hasil Parameter Fairness Sistem}

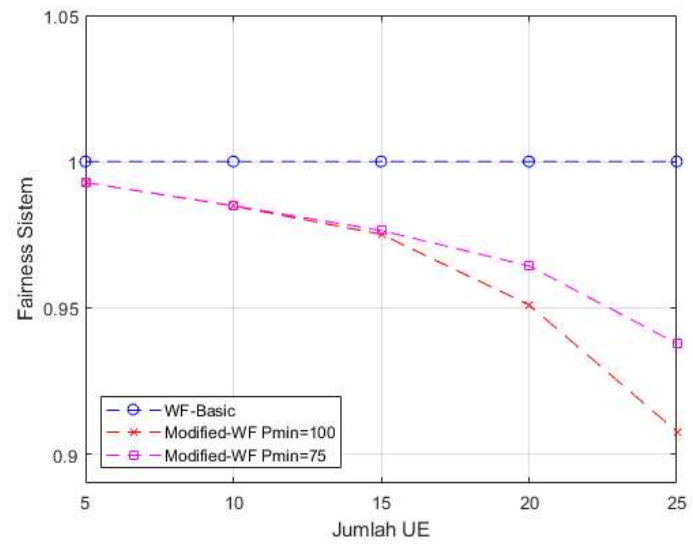

Gambar 7. Perbandingan nilai fairness sistem. 
Pada Gambar 7 menunjukkan bahwa nilai fairness sistem VLC dengan algoritma waterfilling basic menghasilkan nilai fairness sebesar 1 . Hal itu menunjukkan bahwa algoritma waterfilling basic berdampak besar pada pengalokasian daya yang merata atau keadilan sesuai dengan kondisi kanal pada setiap UE. Sedangkan pada grafik nilai fairness sistem VLC dengan algoritma waterfilling modified menghasilkan penurunan nilai fairness yang tidak mencapai 1 .

\subsection{Hasil Parameter Efisiensi Energi}

\subsubsection{Efisiensi Energi Daya LED}

Proses pengujian dengan cara membandingkan nilai rata-rata data rate UE yang dihasilkan ketika nilai daya kirim meningkat dalam rentang 7.5 Watt hingga 9 Watt secara bertahap. Kemudian akan ditentukan target nilai data rate minimum sebesar $1000 \mathrm{Mbps}$. Target data rate sebesar 1000 Mbps ditentukan berdasarkan standardisasi minimum data rate IEEE 802.11ac-2013.

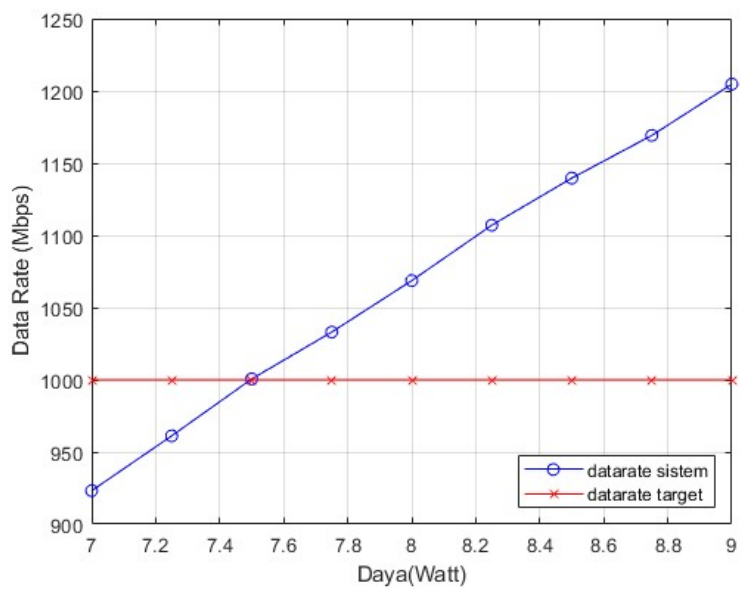

Gambar 8. Perbandingan Data Rate terhadap Variasi Daya Kirim dengan Target 1000 Mbps.

Pada Gambar 8 menunjukkan bahwa daya kirim berbanding lurus dengan data rate sistem. Hasil simulasi sistem VLC menggunakan pengalokasian algoritma waterfilling dapat dijelaskan bahwa ketika daya kirim dinaikkan maka nilai data rate akan meningkat. Daya kirim sebesar 7 Watt dianggap kurang optimal untuk mendapatkan data rate minimum sebesar $1000 \mathrm{Mbps}$. Namun ketika daya kirim dinaikkan sebesar 7,5 Watt maka nilai data rate sistem mampu melampaui target minimum sebesar $1000,57 \mathrm{Mbps}$. Sehingga dari daya kirim sebesar 7,5 Watt menjadi titik optimal dalam mendapatkan nilai efisiensi energi pada sistem VLC menggunakan algoritma waterfilling. Dengan nilai daya yang digunakan (usable energy) sebesar 7,5 Watt dan daya total sebesar 9 Watt maka energi efisiensi dari sistem sebesar 16,67\%.

\subsubsection{Efisiensi Energy dengan Modifikasi Algoritma Waterfilling} Tabel 3. Perbandingan Total Daya Kirim Sistem terhadap Variasi Algoritma Waterfilling.

\begin{tabular}{|l|l|l|l|}
\hline Algoritma & Jumlah daya (W) & Selisih (W) & Eff. Energy (\%) \\
\hline Non-Waterfilling & 9000 & 0 & 0 \\
\hline Basic Waterfilling & 9000 & 0 & 0 \\
\hline Modified WF Pmin. 100mW & 8429 & 571 & $6,3 \%$ \\
\hline Modified WF Pmin. 75mW & 8183 & 817 & $9 \%$ \\
\hline
\end{tabular}


Pada penggunaan algoritma basic waterfilling penggunaan daya sistem untuk 25 UE sebesar 9 Watt, penggunaan ini sama seperti daya pada sistem tanpa algoritma waterfilling. Hal ini menunjukan bahwa algortima waterfilling hanya mengatur alokasi daya kirim pada setiap UE tergantung dengan nilai kanal yang didapatkan. Pada penggunaan algortima modifikasi waterfilling dengan daya alokasi minimum $100 \mathrm{~mW}$ dan maksimum $1800 \mathrm{~mW}$, total daya yang dialokasikan sistem telah berkurang sebesar $571 \mathrm{~mW}$ dengan persentase efisiensi energi sebesar 6,3\%. Pada penggunaan algoritma modifikasi waterfilling dengan daya alokasi minimum $75 \mathrm{~mW}$ dan maksimum 1,8 Watt, total daya yang dialokasikan sistem telah berkurang sebesar $817 \mathrm{~mW}$ dengan persentase efisiensi energi sebesar $9 \%$.

\subsection{Analisis Hasil Parameter Simulasi}

Tabel 4. Perbandingan Keseluruhan Parameter dengan menggunakan Variasi Algoritma Waterfilling.

\begin{tabular}{|c|c|c|c|c|}
\hline Parameter & UE & WF Basic & M-WF Pmin. 100 mW & M-WF Pmin. 75 mW \\
\hline \multirow[t]{5}{*}{$\mathrm{SNR}(\mathrm{dB})$} & 5 & 20,26 & 19,83 & 19,07 \\
\hline & 10 & 14,35 & 14,25 & 14,11 \\
\hline & 15 & 10,79 & 10,69 & 10,59 \\
\hline & 20 & 8,24 & 7,35 & 7,43 \\
\hline & 25 & 6,34 & 5,47 & 4,91 \\
\hline \multirow{5}{*}{ Data rate (Mbps) } & 5 & 135 & 129,8 & 127,4 \\
\hline & 10 & 96,2 & 90,2 & 84,6 \\
\hline & 15 & 73,8 & 69,5 & 64,6 \\
\hline & 20 & 59,1 & 54,4 & 50,01 \\
\hline & 25 & 48,2 & 47,39 & 43,59 \\
\hline \multirow[t]{5}{*}{ Fairness } & 5 & 1 & 0,9928 & 0,9928 \\
\hline & 10 & 1 & 0,9849 & 0,9848 \\
\hline & 15 & 1 & 0,9764 & 0,9751 \\
\hline & 20 & 1 & 0,9643 & 0,9510 \\
\hline & 25 & 1 & 0,9378 & 0,9077 \\
\hline \multicolumn{2}{|l|}{ Daya Total (mW) } & 9000 & 8429 & 8183 \\
\hline \multicolumn{2}{|l|}{ Eff. Energy (\%) } & 0 & 6.3 & 9 \\
\hline
\end{tabular}

Dari hasil simulasi menggunakan algoritma waterfilling maupun modifikasi waterfilling didapatkan nilai parameter seperti pada Tabel 4 di atas. Dengan menggunakan algoritma waterfilling didapatkan nilai SNR, data rate, dan fairness index yang lebih tinggi daripada menggunakan modifikasi waterfilling. Namun daya total yang digunakan oleh sumber tetap sebesar $9000 \mathrm{~mW}$ yang artinya tidak ada penghematan energi. Dengan menggunakan algortima modifikasi waterfilling daya total 47 yang digunakan oleh sumber dapat dihemat sebesar $6,3 \%$ sampai dengan $9 \%$. Penggunaan algoritma waterfilling maupun modifikasi dapat disesuaikan dengan tujuan pengimplementasian baik mengutamakan fairness maksimum atau mengutamakan penghematan energi.

Dari simulasi algoritma waterfilling menggunakan target data rate minimum dengan standar IEEE 802.11ac-2013 yaitu 1000 Mbps atau 1 Gbps didapatkan efisiensi energi sebesar $16,67 \%$ dengan penggunaan daya $7500 \mathrm{~mW}$ untuk 25 UE daripada penggunaan daya $9000 \mathrm{~mW}$, hal ini menunjukan bahwa sistem VLC mampu memberikan data rate target hanya dengan penggunaan $7500 \mathrm{~mW}$ daripada router wifi yang mendukung teknologi IEEE 802.11ac-2013 menggunakan daya $20000 \mathrm{~mW}$. 


\section{KESIMPULAN}

Nilai CQI dan daya terima masing-masing UE sebelum pengalokasian algoritma waterfilling berbanding terbalik dengan jarak, semakin jauh jarak UE dari transmitter maka nilai CQI dan daya yang diterima semakin kecil. Hasil simulasi skema algoritma waterfilling mampu memberikan keadilan daya pada masing-masing UE. Pada algoritma waterfilling nilai average SNR setiap pengalokasian merata sebesar $20,26 \mathrm{~dB}$ sampai dengan $6,34 \mathrm{~dB}$, sedangkan pada algoritma modified waterfilling daya minimum $100 \mathrm{~mW}$ terjadi penurunan SNR menjadi sebesar $19 \mathrm{~dB}$ sampai dengan 5,47dB, pada algoritma modified waterfilling daya minimum $75 \mathrm{~mW}$ SNR sebesar 19,07 dB sampai dengan 4,91 dB. Nilai SNR tersebut mengalami penurunan seiring bertambahnya jumlah UE. Berdasarkan perbandingan average data rate sistem algoritma waterfilling basic mendapatkan nilai data rate sebesar 135 Mbps sampai 48,2 Mbps, algoritma modified waterfilling daya minimum $100 \mathrm{~mW}$ data rate sebesar 129,8 Mbps sampai 47,39 Mbps, algoritma modified waterfilling daya minimum $75 \mathrm{~mW}$ data rate sebesar 127,4 Mbps sampai 43,59 Mbps. Semakin banyak UE yang terhubung maka semakin kecil nilai average

data rate sistem. Dengan menggunakan variasi algoritma modifikasi waterfilling hasil data rate yang didapatkan menjadi lebih rendah namun tidak turun secara siginifikan. Berdasarkan hasil simulasi algoritma waterfilling basic menghasilkan nilai fairness sebesar 1 . Nilai fairness sebesar 1 artinya sistem VLC mampu memberikan keadilan data rate maksimal pada semua posisi dan jumlah UE. Namun hasil simulasi algortima modifikasi waterfilling $100 \mathrm{~mW}$ menurunkan nilai fairness sistem menjadi 0,9928 sampai 0,9378 dan algortima modifikasi waterfilling $75 \mathrm{~mW}$ menurunkan nilai fairness sistem menjadi 0,9928 sampai 0,93077. Dapat disimpulkan bahwa semakin besar daya alokasi minimum yang diberikan maka nilai fairness akan semakin menurun dan semakin bertambah jumlah UE nilai fairness juga menurun. Hasil perhitungan energy efficiency daya lampu VLC 9 Watt menggunakan algoritma waterfilling mendapatkan nilai sebesar $16,67 \%$ dengan nilai daya lampu optimal sebesar 7,5 Watt. Selain itu, dengan menentukan target nilai data rate sistem minimum sebesar 1 Gbps maka dapat menjadi bahan pertimbangan sistem VLC sebagai alternatif transmisi yang efisien dari penggunaan teknologi Wifi dengan standart IEEE 802.11ac-2013 dengan daya router 20 watt. Hasil dari perhitungan efisiensi energi terhadap variasi daya alokasi minimum $100 \mathrm{mw}$ sebesar $6,3 \%$ dan daya minimum $75 \mathrm{mw}$ sebesar 9\%. Hasil ini menunjukan bahwa dengan menggunakan modifikasi algoritma waterfilling dapat menghemat energi daripada penggunaan sistem VLC sebelum menggunakan algoritma waterfilling maupun dengan algortima waterfilling basic. Dapat disimpulkan bahwa dengan batas daya alokasi minimum 75 Watt dan maksimum 1,8 Watt mampu memberikan efisiensi energi paling optimal pada penelitian ini.

\section{DAFTAR RUJUKAN}

Abdelhady, A. M., Amin, O., Chaaban, A., Shihada, B., \& Alouini, M. S. (2019). Downlink Resource Allocation for Dynamic TDMA-Based VLC Systems. IEEE Transactions on Wireless Communications, 18(1), 108-120.

Damayanti, T. N., \& Putri, H. (2014). Sistem Komunikasi Serat Optik. Bandung: Herya Media.

Farabi, N. F., Hambali, A.,\& Darlis, D. (2019). Communication Design and Simulation ACO OFDM for Visible Light Communication. Telkom University, 6(1), 995-1001.

Ghassemlooy, Z., Popoola, W., \& Rajbhandari, S. (2017). Optical wireless communications: System and channel modelling with MATLAB尺. Florida: CRC Press. 
Muthaqien, A., Fahmi, A., \& Andini, N. (2018). Optimasi Resource Allocation Menggunakan Algoritma Particle Swarm Optimization ( PSO ) Pada Sistem Long Term Evolution ( LTE) Arah Uplink. Telkom University, 5(3), 5173-5179.

Pamukti, B., Vinsensius Sigit, W. P., Fahmi, A., Adriansyah, N. M., \& Andini, N. (2019). WaterFilling Random Resource Allocation (W-FRRA) using NOMA for downlink LiFi system. Proceedings - 2019 IEEE Asia Pacific Conference on Wireless and Mobile, APWiMob 2019. (pp. 13-18).

Patterson, M. G. (1996). What is energy efficiency? Concepts, indicators and methodological issues. Energy Policy, 24(5), 377-390.

Praneeth Varma, G. V. S. S., Kumar, A., \& Sharma, G. V. V. (2018, September 24). Resource Allocation for Visible Light Communication using Stochastic Geometry. 2018 11th International Symposium on Communication Systems, Networks and Digital Signal Processing, (pp. 1-6).

Sari, S. M., Fahmi, A., \& Syihabuddin, B. (2015). Algoritma Pengalokasian Resource Block Berbasis Qos Guaranteed Menggunakan Antena MIMO 2x2 Pada Sistem LTE Untuk Meningkatkan Spectral Efficiency. Telkom University, 4(1), 6-8.

Sgora, A., Vergados, D. J., \& Vergados, D. D. (2015). A survey of TDMA scheduling schemes in wireless multihop networks. ACM Computing Surveys, 47, 1-39.

Trihantoro, D. H., Darlis, D., \& Putri, H. (2014). Implementasi Visible Light Communication (VLC) Untuk Pengiriman Teks. Seminar Nasional Teknologi Terapan, (pp. 1-2).

Wan, T., Luo-Kun, L., Xia, Z., \& Chun-Xiao, J. (2017). A Resource Allocation Algorithm Combined with Optical Power Dynamic Allocation for Indoor Hybrid VLC and Wi-Fi Network. Proceedings - 2016 8th International Conference on Computational Intelligence and Communication Networks (CICN) 2016, (pp. 21-27).

Wang, Z., Wang, Q., Huang, W., \& Xu, Z. (2017). Visible Light Communications Modulation and Signal Processing. New Jersey: Wiley.

Wijayanto, A., Sujatmoko, K., \& Pamukti, B. (2019). Impact Of Device Orientation For Visible Light Communication In Closed Room. 2019 4th International Conference on Information Technology, Information Systems and Electrical Engineering (ICITISEE) 2019, (pp.131-135).

Xing, C., Jing, Y., Wang, S., Ma, S., \& Poor, H. V. (2020). New Viewpoint And Algorithms For Water-Filling Solutions In Wireless Communications. IEEE Transactions on Signal Processing, 68, 1618-1634. 